\title{
A surprising steric effect on a tandem cycloaddition/ring-opening reaction: rapid syntheses of difluorinated analogues of (hydroxymethyl)conduritols $\dagger$
}

\author{
John Fawcett, ${ }^{a}$ Andrew C. Moralee, ${ }^{a}$ Jonathan M. Percy, ${ }^{* a}$ Vittoria Salafia, ${ }^{a}$ Mark A. Vincent ${ }^{b}$ and \\ Ian H. Hillier ${ }^{b}$ \\ a Department of Chemistry, University of Leicester, University Road, Leicester, UK LE1 7RH. \\ E-mail: jmp29@le.ac.uk \\ ${ }^{b}$ Department of Chemistry, University of Manchester, Manchester, UK M13 9PL. \\ E-mail:Ian.Hillier@man.ac.uk
}

Received (in Cambridge, UK) 27th January 2004, Accepted 13th March 2004

First published as an Advance Article on the web 8th April 2004

Difluorinated analogues of (hydroxymethyl)conduritols can be synthesised from selected furans and a difluorinated dienophile in two reaction steps.

The literature contains many examples of fluorinated building blocks. ${ }^{1}$ These are either commercially available compounds or readily prepared intermediates that can be manipulated using the important $\mathrm{C}-\mathrm{C}$ bond-forming reactions of modern synthetic chemistry. Few, if any, of these building blocks allow the rapid synthesis of complex fluorine-containing molecules.

We identified cyclic carbonate $\mathbf{4}$ as a side product during the formation of endo and exo cycloadducts $\mathbf{2}$ and $\mathbf{3}$ via the furan DielsAlder reaction of rare difluorinated dienophile ${ }^{2} \mathbf{1}$ in the presence of sub-stoichiometric amounts of stannic chloride (Scheme 1). ${ }^{3}$

We were interested in this product, as it complements species we could obtain by either hydrostannylation/stannate ring opening according to Lautens ${ }^{4}$ or via procedures in which sulfur electrophiles and reductive desulfonation/ring-opening chemistry are used. ${ }^{5}$ Furthermore, though the yield is modest, the product arises in a single reaction step from cycloaddition, followed by highly controlled ring-opening, so the sequence is particularly concise. We therefore decided to investigate further and found that $4(26 \%)$ replaced exo-3 when the cycloaddition was carried out with stoichiometric Lewis acid. \$ However, non-aqueous work-up of a reaction solution led to the exclusive presence of $\mathbf{2}$ and $\mathbf{3}$, as revealed by ${ }^{19} \mathrm{~F}$ NMR: we were only able to observe $\mathbf{4}$ after aqueous work-up. Substituted 2-methyl-, 2,3-dimethyl- and 2,5-dimethylfurans behaved quite differently, failing to afford cyclic carbonates. Instead, only exo cycloadducts were obtained and all attempts to force the reactions led to decomposition.

There is little in the literature that might help to predict how the Lewis acid would bind to $\mathbf{2 / 3}$. A search of the literature revealed only 5- and 6-membered chelates involving stannic chloride. Denmark and Fu have obtained structures for bis-phosphoramide ligand-stannic chloride complexes, ${ }^{6}$ though these include much larger rings. We therefore attempted to grow crystals of a complex between the reactive exo-3 and stannic chloride. Diffusion of hexane into a DCM solution of $\mathbf{3}$ and stannic chloride at room temperature produced air-sensitive crystals of 7a (Fig. 1), which were transferred rapidly to the cold diffractometer stage.§ Clearly,
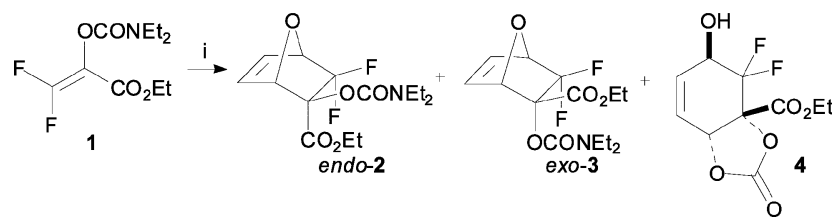

Scheme 1 Furan Diels-Alder reaction of difluorinated dienophile 1. (i) 25 $\mathrm{mol} \% \mathrm{SnCl}_{4}$, furan (2 equiv.), DCM, rt.

$\dagger$ Electronic supplementary information (ESI) available: calculations and Cartesian coordinates for 3-7 (Me substituted for Et throughout); data for 8-10. See http://www.rsc.org/suppdata/cc/b4/b401245c/ this cannot be an intermediate on a direct pathway to 4 . Scheme 2 presents our proposed mechanism for the formation of $\mathbf{4}$.

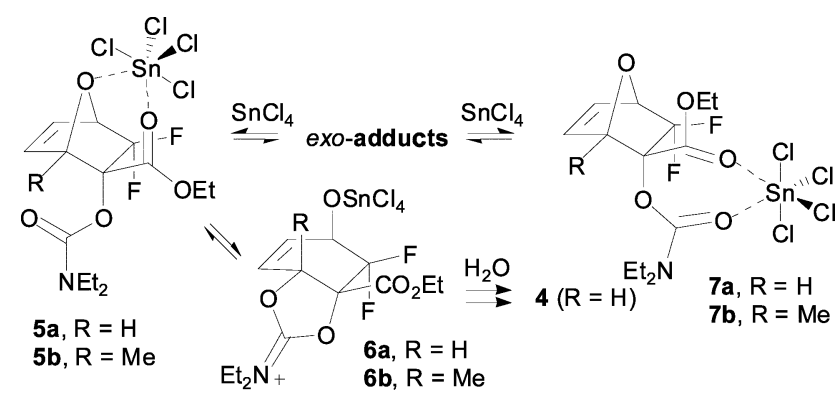

Scheme 2 Proposed mechanism for the formation of cyclic carbonate 4

To trigger ring opening, stannic chloride must first bind to the bridging ether oxygen, which is a poor donor. To compensate for this, 6-membered chelate formation (in 5a) involving carbonyl and ether oxygen donors, which is impossible from the endo cycloadduct, is proposed. Bridge cleavage, which is strain relieving, may then occur reversibly. The proposed intermediate $\mathbf{6 a}$ is transformed into 4 when hydrolysis removes it from the equilibrium. ${ }^{7}$

We have used electronic structure calculations to investigate a number of aspects of this proposed mechanism. ${ }^{8}$ Minima and transition structures were calculated at the B3LYP/6-31G** level, including the effect of the solvent, DCM, using the polarisable continuum model (PCM). These calculations first showed that 5a and 7a differed in energy by only $21 \mathrm{~kJ} \mathrm{~mol}^{-1}$ in favour of $7 \mathbf{a}$, thus confirming the proposed equilibrium between these structures. The proposed intermediate $\mathbf{6 a}$ was confirmed as an energy minimum and the transition structure linking it to reactant $\mathbf{5 a}$ was located, the barrier being $80 \mathrm{~kJ} \mathrm{~mol}^{-1}$. This transition structure showed a high degree of bond cleavage $(\mathrm{C}-\mathrm{O}=2.06 \AA)$, suggesting that the effect of methylation at the bridgehead position is steric rather than electronic. $\dagger$ To investigate this further, the calculations were repeated for the methylated molecules. We now find $\mathbf{7 b}$ to be more stable than $\mathbf{5 b}$ by $42 \mathrm{~kJ} \mathrm{~mol}^{-1}$, with the barrier to the formation of

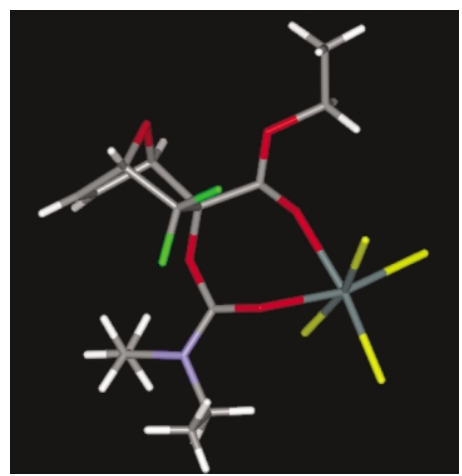

Fig. 1 Crystal structure of air-sensitive complex 7a formed between exo-3 and stannic chloride. 


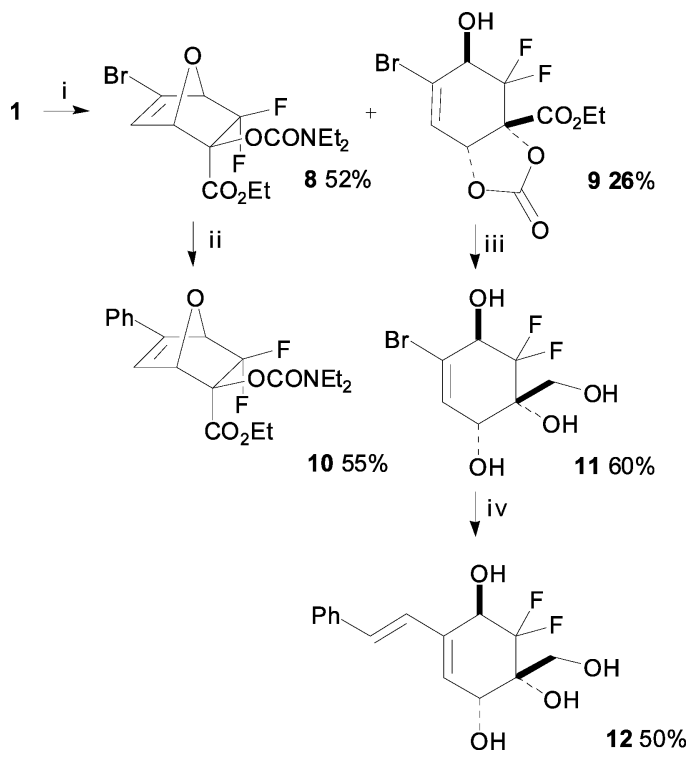

Scheme 3 Diels-Alder reaction of $\mathbf{1}$ with 3-bromofuran and adduct processing: (i) 3-bromofuran (2 equiv.), $\mathrm{SnCl}_{4}$ (1.0 equiv.), $\mathrm{CH}_{2} \mathrm{Cl}_{2}, \mathrm{rt}, 48$ h; (ii) $\mathrm{PhB}(\mathrm{OH})_{2}, \mathrm{Bu}_{4} \mathrm{NBr}, \mathrm{Pd}(\mathrm{OAc})_{2}, \mathrm{H}_{2} \mathrm{O}, 60 \mathrm{~W}, 20 \mathrm{~min}$; (iii) DIBAl-H (6 equiv.), THF, reflux; (iv) $E$ - $\mathrm{PhHC}=\mathrm{CHB}(\mathrm{OH})_{2}, \mathrm{Bu}_{4} \mathrm{NBr}, \mathrm{Pd}(\mathrm{OAc})_{2}, \mathrm{H}_{2} \mathrm{O}$, $\mu \mathrm{W} 60 \mathrm{~W}, 100{ }^{\circ} \mathrm{C}, 20 \mathrm{~min}$.

$\mathbf{6 b}$ (from $5 \mathbf{b}$ ) being increased to $95 \mathrm{~kJ} \mathrm{~mol}^{-1}$. Both these effects will contribute to the observed failure to yield the corresponding carbonate from the 2-methyl (or 2,3-dimethylfuran) cycloadducts.

Cyclic carbonate $\mathbf{9} \S$ and endo-cycloadduct $\mathbf{8} \S$ were obtained in moderate yield from the reaction between 1 and 3-bromofuran, a seldom-used diene ${ }^{9}$ (Scheme 3), as verified by X-ray diffraction analysis of single crystals. This result is in line with our previous conclusion that the steric hindrance at the bridgehead carbon where $\mathrm{C}-\mathrm{O}$ scission occurs is more important for ring opening than electronic effects in the transition state.

The use of the vinyl bromide as a locus for the generation of diversity is an attractive possibility that we propose to explore more fully, since preliminary experiments have yielded encouraging results. Cycloadduct 8 reacted with phenylboronic acid under Leadbetter's aqueous microwave-mediated conditions ${ }^{10}$ to afford 10. Exposure of 9 to excess DIBAl-H provided tetrol 11 in moderate yield; a styryl group was then introduced via the coupling reaction.

Potentially, these reactions afford extremely rapid access to a very wide range of functionally rich difluorinated cyclohexene derivatives, though there is considerable scope for optimisation.

We thank the EPSRC (GR/M94922) for grants (fellowship to A. C. M., studentship to V. S.).

\section{Notes and references}

$\$$ Cycloaddition with stoichiometric tin(IV) chloride: preparation of $\mathbf{3}$ Tin(Iv) chloride ( $2 \mathrm{mmol}, 1.9 \mathrm{~mL}$ of a $1.03 \mathrm{M}$ solution in DCM) was added slowly to a mixture of alkenoate $1(2 \mathrm{mmol}, 0.5 \mathrm{~g})$ and furan (4 mmol, 0.3 $\mathrm{mL})$ in DCM (3 mL); the mixture was stirred at room temperature for $36 \mathrm{~h}$. The mixture was diluted with water $(5 \mathrm{~mL})$ and extracted with ethyl acetate $(3 \times 15 \mathrm{~mL})$. The combined organic extracts were dried $\left(\mathrm{MgSO}_{4}\right)$ and concentrated in vacuo to leave an orange oil $(0.61 \mathrm{~g})$, which was purified by column chromatography ( $20 \%$ diethyl ether in light petroleum) to afford endo adduct 2a $(0.22 \mathrm{~g}, 34 \%)$ and cyclic carbonate $\mathbf{3}(0.14 \mathrm{~g}, 26 \%)$ as cubic crystals; mp $61-62{ }^{\circ} \mathrm{C} ; R_{\mathrm{f}}(20 \%$ diethyl ether in light petroleum) 0.05 ; (Found: $\mathrm{C}, 45.66 ; \mathrm{H}, 3.70 ; \mathrm{C}_{10} \mathrm{H}_{10} \mathrm{~F}_{2} \mathrm{O}_{6}$ requires: $\mathrm{C}, 45.46 ; \mathrm{H}, 3.82 \%$ ); $v_{\max }$ (film) $/ \mathrm{cm}^{-1}: 3538 \mathrm{~m}$ br $(\mathrm{OH}), 2996 \mathrm{~m}(\mathrm{C}-\mathrm{H}), 1846 \mathrm{~m}(\mathrm{C}=\mathrm{O}), 1750 \mathrm{~m}(\mathrm{C}=\mathrm{O})$, $1473 \mathrm{w}(\mathrm{C}-\mathrm{C}), 1315 \mathrm{~m}(\mathrm{C}-\mathrm{O}), 1229 \mathrm{~m}(\mathrm{C}-\mathrm{O}), 1118 \mathrm{~m}(\mathrm{C}-\mathrm{O}) ; \delta_{\mathrm{H}}(300 \mathrm{MHz}$, $\left.\mathrm{CDCl}_{3}\right)$ : 6.15-6.09 $(1 \mathrm{H}, \mathrm{m}), 5.96-5.91(1 \mathrm{H}, \mathrm{m}), 5.48(1 \mathrm{H}, \mathrm{d}, J 4.0)$ $4.68-4.61(1 \mathrm{H}, \mathrm{m}), 4.42-4.32(2 \mathrm{H}, \mathrm{m}), 3.66(1 \mathrm{H}$, br s $), 1.34(3 \mathrm{H}, \mathrm{t}, J 7.2$ $\mathrm{Hz}) ; \delta_{\mathrm{C}}\left(75 \mathrm{MHz}, \mathrm{CDCl}_{3}\right): 164.2\left(\mathrm{~d},{ }^{4} J_{\mathrm{C}-\mathrm{F}} 1.7\right), 151.3,133.5\left(\mathrm{dd},{ }^{3} J_{\mathrm{C}-\mathrm{F}} 5.9\right.$, $1.4), 122.0\left(\mathrm{~d},{ }^{4} J_{\mathrm{C}-\mathrm{F}} 1.1\right), 116.6\left(\mathrm{dd},{ }^{1} J_{\mathrm{C}-\mathrm{F}} 256.6,250.9\right), 80.6\left(\mathrm{dd},{ }^{2} J_{\mathrm{C}-\mathrm{F}}\right.$ $33.1,23.5), 76.8\left(\mathrm{~d},{ }^{3} J_{\mathrm{C}-\mathrm{F}} 2.3\right), 65.2\left(\mathrm{dd},{ }^{2} J_{\mathrm{C}-\mathrm{F}} 27.1,20.9 \mathrm{~Hz}\right), 64.2,13.7 ; \delta_{\mathrm{F}}$ $\left(282 \mathrm{MHz}, \mathrm{CDCl}_{3}\right):-115.3\left(1 \mathrm{~F}, \mathrm{~d},{ }^{2} J_{\mathrm{F}-\mathrm{F}} 261.5\right),-125.9\left(1 \mathrm{~F}, \mathrm{dd},{ }^{2} J_{\mathrm{F}-\mathrm{F}}\right.$ $\left.261.5,{ }^{3} J_{\mathrm{F}-\mathrm{H}} 13.4 \mathrm{~Hz}\right) ; \mathrm{m} / \mathrm{z}(\mathrm{CI}): 283\left(100 \%,[\mathrm{M}+\mathrm{Na}]^{+}\right)$.

$\S$ Crystal data for 6 (mp not measured): $\mathrm{C}_{14} \mathrm{H}_{19} \mathrm{Cl}_{4} \mathrm{~F}_{2} \mathrm{NO}_{5} \mathrm{Sn}, M=579.8$ monoclinic, $a=10.4879(11), b=18.8071(19), c=10.7203(11) \AA, \beta=$ $102.993(2)^{\circ}, U=2060.4(4) \AA^{3} ; T=150(2) \mathrm{K}$; space group $P 2{ }_{1} / n, Z=4$, $\mu\left(\mathrm{Mo}_{\mathrm{K}}\right) 1.802 \mathrm{~mm}^{-1} ; 10971$ reflections measured, 4033 unique $\left(R_{\mathrm{int}}=\right.$ $0.0261)$, which were used in all calculations; $R_{1}=0.0278, w R_{2}=0.0651$; the final $w R\left(F^{2}\right)$ was 0.0639 (all data). For 8 (mp $71-72{ }^{\circ} \mathrm{C}$ ) $\mathrm{C}_{14} \mathrm{H}_{18} \mathrm{BrF}_{2} \mathrm{NO}_{5}, M=398.2$; monoclinic, $a=11.6660(9), b=8.0535(6)$, $c=18.3629(14) \AA, \beta=102.7150(10)^{\circ}, U=1682.9(2) \AA^{3} ; T=150(2) \mathrm{K}$; space group $P 2{ }_{1} / c, Z=4, \mu\left(\mathrm{Mo}-\mathrm{K}_{\alpha}\right) 2.486 \mathrm{~mm}^{-1} ; 12743$ reflections measured, 3310 unique $\left(R_{\text {int }}=0.0269\right)$, which were used in all calculations; $R_{1}=0.0417, w R_{2}=0.0914$; the final $w R\left(F^{2}\right)$ was 0.0888 (all data). For 9 (mp 123-125 ${ }^{\circ} \mathrm{C}$ ): $\mathrm{C}_{10} \mathrm{H}_{9} \mathrm{BrF}_{2} \mathrm{NO}_{6}, M=343.1$; monoclinic, $a=7.0091(8)$, $b=11.5134(13), c=14.9095(17) \AA, \beta=94.404(2)^{\circ}, U=1199.6(2) \AA^{3}$; $T=150(2) \mathrm{K}$; space group $P 2_{1}, Z=4, \mu\left(\right.$ Mo-K $\left.{ }_{\alpha}\right) 3.474 \mathrm{~mm}^{-1} ; 8057$ reflections measured, 4055 unique $\left(R_{\mathrm{int}}=0.0236\right)$, which were used in all calculations; $R_{1}=0.0328, w R_{2}=0.0768$; the final $w R\left(F^{2}\right)$ was 0.0768 (all data). CCDC 229969-229971. See http://www.rsc.org/suppdata/cc/b4/ b401245c/ for crystallographic data in CIF or other electronic format.

1 J. M. Percy, Top. Curr. Chem., 1997, 193, 131.

2 For the only previous example of a difluorinated alkenoate dienophile, see: J. Leroy, H. Molines and C. Wakselman, J. Org. Chem., 1987, 52, 290; the application of DFT methods to a monofluorinated dienophile is described in: M. Essers, C. Muck-Lichtenfeld and G. Haufe, J. Org. Chem., 2002, 67, 4715.

3 P. J. Crowley, A. C. Moralee, J. M. Percy and N. S. Spencer, Synlett, 2000, 1737.

4 M. Lautens and W. Klute, Angew. Chem., Int. Ed. Engl., 1996, 35, 442; A. Arany, P. J. Crowley, J. Fawcett, M. B. Hursthouse, B. M. Kariuki, M. E. Light, A. C. Moralee, J. M. Percy and V. Salafia, Org. Biomol. Chem., 2004, 455.

5 P. J. Crowley, J. Fawcett, B. M. Kariuki, A. C. Moralee, J. M. Percy and V. Salafia, Org. Lett., 2002, 4, 4125.

6 S. E. Denmark and J. P. Fu, J. Am. Chem. Soc., 2003, 125, 2208; for a 7-membered chelate involving ether oxygen ligands, see: K. Ishihara, $\mathrm{H}$ Ishibashi and H. Yamamoto, J. Am. Chem. Soc., 2002, 124, 3647.

7 A referee suggested an alternative explanation in which water reacts with 5a, which then progresses irreversibly. We cannot disprove this suggestion, but must point out that our hypothesis does appear to be strongly supported by the computational findings.

8 M. J. Frisch, G. W. Trucks, H. B. Schlegel, G. E. Scuseria, M. A. Robb, J. R. Cheeseman, V. G. Zakrzewski, J. A. Montgomery, Jr., R. E Stratmann, J. C. Burant, S. Dapprich, J. M. Millam, A. D. Daniels, K. N. Kudin, M. C. Strain, O. Farkas, J. Tomasi, V. Barone, M. Cossi, R. Cammi, B. Mennucci, C. Pomelli, C. Adamo, S. Clifford, J. Ochterski, G. A. Petersson, P. Y. Ayala, Q. Cui, K. Morokuma, P. Salvador, J. J. Dannenberg, D. K. Malick, A. D. Rabuck, K. Raghavachari, J. B. Foresman, J. Cioslowski, J. V. Ortiz, A. G. Baboul, B. B. Stefanov, G Liu, A. Liashenko, P. Piskorz, I. Komaromi, R. Gomperts, R. L. Martin, D. J. Fox, T. Keith, M. A. Al-Laham, C. Y. Peng, A. Nanayakkara, M. Challacombe, P. M. W. Gill, B. G. Johnson, W. Chen, M. W. Wong, J. L. Andres, C. Gonzalez, M. Head-Gordon, E. S. Replogle and J. A. Pople, Gaussian 98, Gaussian, Inc., Pittsburgh, PA, USA, 2001.

9 M. G. Van Campen and J. R. Johnson, J. Am. Chem. Soc., 1933, 55, 430; D. G. Batt, D. G. Jones and S. La Greca, J. Org. Chem., 1991, 56, 6704.

10 N. E. Leadbeater and M. Marco, J. Org. Chem., 2003, 68, 888-892. 